\title{
Ideal Model in the Implementation of National Insight Policies for Handling Social Conflict in Pandeglang Regency
}

\author{
Rusdjiman Soemaatmadja ${ }^{1}$, Tjahja Supriatna ${ }^{2}$, Hyronimus Rowa ${ }^{3}$, Kusworo ${ }^{4}$ \\ 1,2,3,4 Institut Pemerintahan Dalam Negeri (IPDN), Indonesia \\ Email: jimans1957@gmail.com
}

\begin{abstract}
Pandeglang Regency is one of the regencies located in Banten Province which is a strategic area because it is close to the capital city of the Republic of Indonesia. Its proximity to the capital causes Pandegalang Regency to have the potential for high social conflict. This is supported by data showing that the number of conflicts in Pandeglang Regency was the highest in Banten Province in 2011 although there was a tendency to decrease in the following year. To suppress the occurrence of social conflicts in Pandeglang District, the local government has implemented a National Insight Policy with a collaborative governance perspective. The research describes the factors that influence the implementation of these policies and tries to formulate an ideal method that can be used in the application of a national insight policy. This study uses a qualitative approach so that in interpreting the conditions of the actors, it is further developed by means of triangulation analysis. The results of the study found that there were several factors that influenced the implementation of the national insight policy such as the insufficient capability of the national insight education center team, low community participation, limited budget. In this study, researchers also tried to design a model for implementing the national insight policy in social conflict management.
\end{abstract}

Keywords: National Insight, Collaborative Governance, Social Conflict.

\section{A. INTRODUCTION}

The Indonesian nation consists of various ethnic groups, regional languages, customs, religions, and has various cultural backgrounds. This diversity remains in one unity, this is emphasized by the slogan "Bhineka Tunggal Ika" which means that different is still one thing. Even the islands are different, but they are still one unit (Lestari, 2016). In this diversity, the Indonesian nation should develop itself to become a nation that has its rightful place alongside other nations in the world. Building a whole human being means building integrity in human resources to play a full role as an individual and as a citizen of the nation (Lon, 2019).

It cannot be denied that the diverse conditions of the Indonesian nation have high potential for social conflict, especially in terms of ethnicity, religion and race (SARA). These conditions can affect the behavior of individuals and groups as well as individuals with other groups. The occurrence of this social conflict can lead to acts of violence (Oberschall, 1973). Social conflict arises not by itself and cannot be imagined as simply as possible. Conflict can occur due to inequality and personal interests within an organizational component (Rubin et al, 1994). The community in general feels that there are conflicts such as family conflicts, territorial conflicts, personal conflicts, conflicts between countries that can lead to war or violence. The 
existence of social conflicts can lead to social welfare in society because it is against the principle of integration which builds awareness of equality as fellow social beings created by God as brothers. Conflicts occur not only between communities, but also between communities and government (Knight \& Jack, 1992).

One of the views on conflict from Robbin (2016) said that conflict is the conflict paradox, which means the view that conflict is considered to improve the performance of social groups. But in groups in general trying to minimize social conflict. Soekanto (1983) said that social conflict is a social process of individuals or groups who try to fulfill their objectives by opposing the opposing party accompanied by threats and violence. In contrast to Robert M. Z. Lawang (2015), who said that conflict is a struggle to gain value, status, and violence when the goals of the conflicting parties are not only to get profit but also to subdue their rivals.

The potential for social conflict in Indonesia is a real threat. So to suppress the potential for social conflict, it is necessary to formulate a policy which is expected to eliminate or at least reduce the occurrence of social conflict in Indonesia. One of the policies implemented is the policy of national insight.

National insight consists of the word insight and nationality. Insight comes from the word "wawas" which in language means views, reviews, visions, sensory responses, and in other terms insight means understanding or belief about a thing, perspective, way of review and way of sensory responses. Nationality comes from the word nation or "nation" which is defined as a group of people who come from the same ancestors (Kodhi \& Soejadi, 1989). Nationality comes from the word nation or nation. According to Benedict Anderson (2004) nation is defined as an imagined political community. Nation was initially more in the form of mere shadow work, but later the nation was imagined as a community and accepted as a strong and deep friendship. This opinion is very similar to that of Ernest Renan. Ernest Renan argues that a nation is the existence of one life, one principle of reason, which occurs from two things: First, it has the same history. Second, they must have the will, the desire to live as one or the desire to live together (Soekarno, 1965). Meanwhile, the concept of nationality, according to Hans Kohn (1958), is expressed as a notion that argues that the highest personal loyalty must be submitted to the national state.

Thus it can be concluded what is actually contained in the national insight, namely a perspective about oneself and its environment which is not based on the same ethnicity, descent, regionalism, religion or belief as well as customs or regional culture. With such a viewpoint, attitudes of life, ways of thinking and ways of working will grow that are not placed on the division of the nation based on ethnic, regional, descent, religion and belief linkages. In addition, there will also be an attitude to life, ways of thinking and ways of working that refer to national unity and unity. Besides that, this perspective also has elements of unity, freedom, equality, personality, and achievement which constitute pride for citizens. In addition, there are other elements, such as language, region, religion, ancestral heritage, art, and various kinds of institutions that live in society. This perspective requires self-awareness and a sense of responsibility in a person or a community to 
participate in the existence of the nation and improve the quality of life of the nation (Hadi, 2009).

The values of the National Insight that are the glue of the Unitary State of the Republic of Indonesia contain meanings that must be the view of life for all citizens, but historical facts illustrate that there appears to be a phenomenon of events that threaten the existence of Pancasila values. Incidents that occurred in an extreme manner through rebellion and soft movements such as the inculcation of antiPancasila and NKRI values continued to occur in the course of the life of the nation and state. The description described above is historical evidence that national unity is currently under serious threat.

An overview of national insight that has been transformed into a National policy, namely Law number 17 of 2004 concerning the National Long-Term Development Plan 2005-2015, further elaboration in this policy is the cultivation of national values through education for the community on an ongoing basis which is oriented towards the concept of Confucius and mel cyberermen (Infopublik, 2016). As a policy, the national insight is an inseparable part of the life of the state so that the government as a Policy Maker must always carry out evaluation activities on the cultivation of national values, so that policies that are born can become the glue for national differences through awareness of national values. The national insight policy apart from being a government product and the values of the nation's life is also the result of the Indonesian nation's political process as an effort to maintain the integrity of the Republic of Indonesia, and to prevent the State from being divided in society (Wasistiono, 2015).

Pandeglang Regency is one of 8 Regencies / Cities in Banten Province which is located at the western tip of Java Island. Geographically it is located between $6^{\circ} 21^{\prime}$ $7^{\circ} 10$ 'South Latitude and $104^{\circ} 48^{\prime}-106^{\circ} 11^{\prime}$ East Longitude, has an area of 2,747 Km2 $(274,689.91$ ha), or $29.98 \%$ of the area of Banten Province. Pandeglang Regency has a land area of 2,782.89 Km2 or 29.98\% of the area of Banten Province, with a coastline of $230 \mathrm{Km}$ and has 13 (thirteen) small islands with the largest Panaitan Island. Pandeglang Regency has 35 (thirty five) sub-districts, 13 (thirteen) wards and 326 (three hundred and twenty six) villages as of 2015, with the widest sub-district, namely Cikeusik, covering an area of $322.76 \mathrm{Km} 2$, while the smallest sub-district is Labuan with an area of ?? $15.66 \mathrm{Km} 2$, with administrative limits:

1. Serang Regency in the north;

2. To the south is bordered by the Indonesian Ocean;

3. To the west is bordered by the Sunda Strait;

4. East side is bordered by Lebak Regency

Several social problems that exist in Pandegalang Regency can trigger social conflicts. These problems include, among other things, there are still many underdeveloped areas, the poverty rate is still quite high, around $9.50 \%$, the high level of unemployment is $7.03 \%$, the low level of public education, the inadequate quality of health services etc. 
Pandeglang Regency is an area prone to social conflict. Throughout 2011, there were 11 social conflicts in which 7 sub-districts and 24 villages were conflict locations with the background of land conflicts that claimed lives and material victims. Indeed, in the following years there was a decrease in the incidence, but the conflict still persists. Therefore, to prevent or at least reduce the occurrence of social conflicts the Pandeglang Regency Government implements a policy of national insight. Based on this background description, the authors are interested in researching and evaluating the factors that influence the implementation of national insight policies and finding the ideal method of implementing policies in the Collaborative Governance perspective.

\section{B. METHOD}

This study uses a qualitative approach with a focus on the factors that influence the implementation of the National Insight Policy and the appropriate method of implementing the policy. The qualitative approach was chosen because the researcher wanted to deepen the understanding of all parties related to the national insight individually (Effendy, 2010).

According to Effendy (2010), qualitative research is research that describes and analyzes human behavior individually and in groups, principles or beliefs, understandings or thoughts, and perceptions or assumptions. The aim of qualitative research is to develop a theory from the results of comparisons with other similar theories, which researchers consider to be both subjective and objective.

According to Sugiyono (2010) the qualitative research method can be interpreted as a research method based on the post-positivism/interpretive philosophy, used to examine the conditions of natural objects, (as opposed to experiments) where the researcher is the key instrument, the data collection technique is triangulated (combined), data analysis is inductive/qualitative, and the results of qualitative research emphasize meaning rather than generalization.

\section{RESULT AND DISCUSSION}

\section{Factors that Influence the Implementation of the National Insight Policy} The Capability of the National Insight Education Center Team is Not in Accordance

The essence of a policy is at the implementation / implementation stage. This is based on the presence of a policy intended to answer problems faced by society. In this context, the problems of national and state life make the implementation of the national insight policy very necessary to reorganize the view of life together as citizens.

The collaborative process which is based on the inculcation of national values as established by the local government is a necessity that requires capabilities that are not only related to national insight material but also have experience from the practice of national insight values. The ability of each actor involved in national education is considered very decisive, this is because the coaching process really 
requires understanding (Understanding) both in designing methods of developing national insight as well as in delivering national insight material.

The capability of the national insight education center team will be largely determined by the abilities of the individual actors involved. The dynamics of the collaboration process really requires the quality and capability of the actors involved so that the collaboration process runs based on a mutually agreed consensus. However, in reality the collaborative process in the implementation of national insight education in Pandeglang Regency is still dominated by formal institutional actors whose election is based on the position they are assigned. This is at least still far from the expectations of professionalism in the process of national insight education because the backgrounds of the actors do not necessarily match the aims and objectives of national insight education.

The competence of each actor involved in the national insight education collaboration must be based on the professionalism of each actor. A professional person is required to have the ability to master certain knowledge in depth and also have creativity and even the ability to develop innovations for the knowledge they have. In detail, competence has not become the main benchmark in the formation of the national insight education team. The formation of the team is still based on the position or status of the government organization.

The phenomenon of the difference between the expectations set forth in the policy document and the implementation of policies in the implementation of the national insight policy seems very contradictory. This fact becomes an obstacle in developing the value of the national insight that takes place in society. It is necessary to improve the implementation of policies by referring to the policy documents that have been printed so that the implementation process of the national insight policy can be effective and efficient.

The capabilities expected to be possessed by facilitators of implementing national insight policies who act as: facilitators, mediators, communicators and motivators as described in the strategic plan of the National Unity and Politics Agency are different from its implementation which causes instability in the view of the community in the life of the nation and state in Pandeglang Regency. The inability to implement the idea of National Insight through competent facilitators creates various conflicts in the community.

This becomes a heavier challenge because the level of public trust in the government is very low, and the influence of religious views is very important in people's lives. "The trauma experienced by the community at a time when the inculcation of Pancasila values in the community through government doctrine in the past led to the reluctance of the community to study the value order of the national insight as the glue of the nation". Even though the accountability report states the target is $100 \%$ accomplished through 10 activities, in reality the outcome of implementing the national insight policy is the quality of people's lives.

The importance of inculcating the value of the National Insight in various aspects and levels of community life really requires actors who understand the 
substance of the National Insight as a national value, besides that they have the competence to implement the facilitator method both through the education process and the training process that makes participants interested. to try to understand the value of the National Insight. This is in line with the view of the policy concept which views that the success of a policy will greatly depend on the nature of the individual and the target group of the policy and the policy implementer.

The government as the policy maker as well as the implementer should have the appropriate competence in order to provide services and at the same time regulate the behavior of the target group. This is an obstacle in the implementation of the national insight policy because it has not had a positive impact on the expectations of the implementation of the national insight policy

The view above, explains that the challenge of implementing the value of national insight becomes a very tough job when the Pandeglang district government does not implement innovations in implementing these values for the community. To develop this innovation, it must be directly supported by actors who have competence and capability in developing methods of planting values in society.

\section{Low Public Participation}

The survival of the Indonesian nation is highly dependent on the society's point of view on the values that form the basis of social interaction in the community, one of which is the National Insight. As a value that must remain alive as the glue of the multicultural life of Indonesian society, support from the community is urgently needed as the subject of actualizing the values of the national insight.

The community as the subject of implementing the national insight policy is also part of the policy environment which must make the policy have to adjust its environment so that it can be accepted and implemented in people's lives. The policy environment in the framework of the National Insight includes the community as the target of a national insight policy. As a policy target in a democratic value order Community participation is very much needed to ensure that national insight policies can run well.

The contextual change of government from hierarchy to heterarchy forces the government in implementing policies to be open, inclusive, and collaborative. These changes also require the public to participate directly and not only position themselves as policy targets but also as policy actors. Especially the implementation of the national insight policy has a key point of success in society. Related to that, the view of the research informants who stated that: "the role of the community, especially in forming a strong environment of the value of national insight, is still lacking. This can be seen from many families who do not care about their family members in participating in demonstration activities in Indonesia. The capital and acts of terrorism involving residents of Pandeglang Regency".

In a conceptual view, participation is related to three dimensions, namely: the contribution dimension, the organizational dimension and the empowerment 
dimension. In matters related to national insight, the three dimensions are an integral part, however, through this discussion the authors can explain the challenges faced with regard to participation from the three dimensions, including:

a. Contribution Dimensions, the National Insight policy framework, the contribution of society is a determinant of success in achieving the goal of a national insight policy. Given the insight that Indonesian nationality grows and develops in society and its values are the result of previous contributions from society. Related to this, it becomes a challenge now that the reduced community contribution is due to the very low level of trust in the government, especially in Pandeglang Regency. In addition, the contribution of society to build views related to the values of an inclusive national insight is very difficult because of the influence of the narratives of religious views that are built to divide the relationships of people with different beliefs and beliefs. This is contrary to the view of the national insight which views society as a unity in the differences they have. The lack of respect for the multicultural environment in the community is part of the people's perspective because they think that everything is the responsibility of the government. It is also very strongly influenced by the socio-economic environment and the level of education which is still very low. Pandeglang Regency, whose position is also quite remote, makes the contribution of the community to the implementation of the values of national insight very difficult, because the people are busy meeting their respective needs.

b. The Organizational Dimension, becomes a separate obstacle in implementing the national insight policy, after forming a facilitator team for Pandeglang district, the impression of organizing the National Insight Education Center Facilitator Team is only a formality in eliminating the obligation to form an embedded organization without paying attention to the competence of the team members involved. This has greatly influenced the public's interest in deepening knowledge of national insight. Institutionally, it is clear that the organization of the National Insight in the Vision of the National and Political Unity Body of the Pandeglang Regency is very clear that: Creating a National, Democratic, Safe and Comfortable Society Towards a Prosperous Pandeglang in 2020. Based on this vision, the National Unity Body and Politics have the main program to revive the return the values of national insight in the life of the nation and state operationally. However, the actualization of the Vision rarely involves the community in policy analysis and decision making. The expected community participation is a form of public awareness of the responsibility to care for the value order of life together. The view of the community regarding government policies is an agreement of the elites which is always felt to make people's lives more difficult, creating obstacles to community involvement in policy implementation.

c. Dimensions of Empowerment, the context of policy implementation. National insight should be implemented with empowerment values so as to build 
independence in people's thinking about the values of national insight in the life of the nation and state. The empowerment process in the context of collaboration and policy, by involving the community in all aspects of decision making, from planning, formulation to policy implementation and evaluation. The fact that what happens is that community involvement is only a target of national insight policy, where involvement from planning to formulation is very limited only at the level of village and government officials. This fact makes people apathetic towards the government policies of Pandeglang Regency. In fact, it requires adequate awareness of citizens and state administrators in carrying out their obligations and responsibilities. In the midst of the pressure of various problems pressing the nation.

\section{Limited Budget for the Implementation of Language Education}

The existence of a dignified nation and state is a manifestation of the ideals and goals of national and state life. Better understanding and implementation of the National Insight in the realm of private and collective life as well as in the public sphere will greatly determine the survival of the nation and state. This awareness of life should be supported by the government as state administrator. The government as the controller of regional financial management is an important actor in government administration. Vision to become a road map for governance, in which the Regent's Vision and Mission does not explicitly mention the inculcation of national values in people's lives.

Budget support is a necessity in supporting a local government policy. Pandeglang Regency needs more budget to ensure the value order in the community is based on the awareness of living together based on the values of the National Insight. This is in line with the view of the research informant who said that: "It is rather difficult to implement the National Insight Policy with the current budget allocation, how could our target be residents of Pandeglang Regency, but budget allocation is still very limited on the grounds that it is not a priority program".

The limited budget with a non-optimistic target could make the effectiveness of the implementation of the National Insight policy slow in solving problems in people's lives. It turns out that the priority of the activity program takes into account the resources owned by the National Unity and Political Body, including the budget.

\section{Model of National Insight Policy Implementation}

Building a model must consider the situations and conditions that surround the reality so that it is specific. Moreover, in social science, the dynamics are very fluid, so it is influenced by many factors. This means that one model cannot be applied exactly to regions with different situations and conditions. The model generated from the results of social science research cannot be applied in general (general ability), it can only be applied to other areas as long as the prerequisites are met (transfer ability). 
The model is an abstraction or simplification of the facts found in research. This research, which is focused on the Concept of Collaboration and National Insight policy implementation, has its own challenges in combining the fact of research on the collaborative process and policy implementation of a national value in a society that is facing social, political and national problems. The model in this study is intended to modify or improve the Collaboration model developed by Ansell and Gash because of the differences in reality found in this study. The effort of developing a model in this research is carried out to make it easier to understand the reality, social, political and nationality of the research locus through a series of connected concepts.

The research phenomenon under study is how the insight of nationalism as a view of life together conceptually and in practice should be applied collectively or can be understood as a collaborative process in the life of the nation and state. After observing and analyzing, there are many things that are found in the research process that need to be corrected related to research problems. Whereas access to participate in policy implementation National insight is still the main obstacle where actors in the policy implementation process are still dominated by the government. This condition forms the public mindset to not be participatory in the implementation of the national insight policy, and considers the problems of national life as the sole responsibility of the government.

Apart from the limited access for the public to be involved, obstacles are also faced through an overly formalistic process that is carried out in the policy implementation process. This is a challenge in itself in implementing policies with a national perspective because the current methods of implementing policies are very dynamic and diverse. This makes the community as the subject of policy implementation less interested in trying to understand the meaning of the policy being implemented. These constraints are also caused by other obstacles that are owned by the government as the leading sector in policy implementation due to the limited competence of human resources who play a role as implementers. What is meant by the limited competence of the Implementers is. Whereas since policies have been formulated by policy designers, the national perspective has not become data and facts faced by the community as a basis, they only formally formulate policies with mere assumptions, so that the resulting policies only accommodate government parties as actors in implementing national insight policies. This was revealed from the policy of the national insight education center which was only filled by government circles that did not yet have the competence to instill the values of Pancasila ideals for the community.

Analysis of the problematic situation will be described in a conceptual model "Integrated Collaboration Process" (INCOLCES) which is expected to be a solution for solving problems of national life through actualization of the values of national insight as shared values in establishing national life which will be described as follows: 


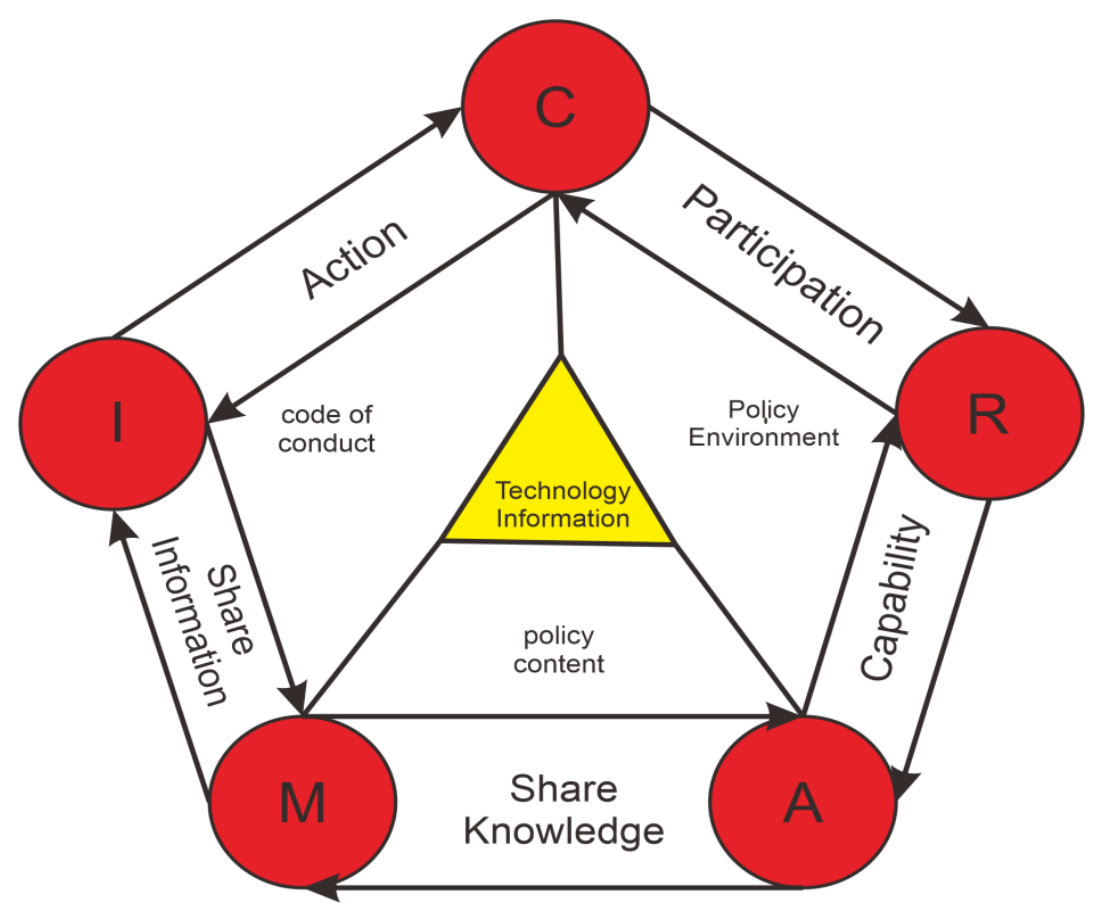

Information: C: Citizen, R: Regulator, A: Academic, M: Media, I: Implementor Policy

Figure 1 Collaboration Model: Integrated Collaboration Process

The national perspective is the perspective of the Indonesian nation regarding itself and its environment, prioritizing territorial unity and unity in the conduct of social, national and state life. National unity or integration is cultural in nature and does not only have structural nuances, it contains a unity of ideology, political unity, socio-cultural unity, economic unity, and unity of defense and security. The national perspective determines how the nation can make use of the country's geographical, historical, socio-cultural, economic and political conditions as well as defense and security in achieving goals and ensuring national interests. The national insight determines the nation's position in the relationship with fellow nations and in association with other nations in the international world.

The national insight contains a commitment and a spirit of unity to ensure the existence and improvement of the quality of life of the nation and requires adequate knowledge of present and future challenges as well as various potentials of the nation. The framework for modeling the above research illustrates a simplification of social facts that occur and are relevant to research. to solve research problems through the relationship of concepts between actors involved in the implementation of national insight policies and connected actions between actors who have interests through action and conceptual frameworks that direct the process of collaborating on national insight policies for the better in Pandeglang Regency.

The model framework described above consists of Actor Dimensions, Actions, Policy Construction, and Concepts. The dimensions of actors who play a role in the collaboration of national insight policies consist of: Citizen, Regulator, Academic, Media, and Implementer. All the actors described in the odel above represent each 
component with an interest and obligation in implementing the national insight policy. Citizens or commonly known by the public must at least be more active in providing input in decision making, this is confirmed by the opinion of Öberg \& Uba, (2014) who state that: "the citizens deliver more reason-based input to democratic decision making" when they prepare and apply their interests and efforts in groups (collective level) than when they participate as individuals".

In relation to the formulation of a policy the regulator has a strategic and vital position, the role of the regulator is required to strive to be able to define the issue of national insight to be answered through the policies it formulates. At least the formulation of policies carried out by regulators was carried out based on Policy Networks, this is in line with the views of Gajendra Sharma, Xi Bao and Li Peng who said that: "Policy networks focus on the diffusion of policy innovation, agenda setting, and institutional support for collective action".

The intended policy formulation pattern must also take into account the roles of various interested parties, namely all citizens who are the subject and object of the National Insight policy. In connection with the next academic actor. It is in line with the view above, that policy networks need capability for regulatory actors, for that it really requires the participation of academic actors in the framework of increasing the capability of regulators to design policy innovations that are more effective in solving problems of national insight faced by society.

The dependence that academic actors have on accurate information based on the facts that occurs can not only be fulfilled through the literature studied but more accurately obtained from the media as a channel of information to the public. Steps that need to be done softly through knowledge sharing so that this knowledge can be transformed into a basis used for increasing the capacity of regulators and also as a means to increase the media's ability to capture the information needed in the framework of implementing policies by actors implementing the National Insight policy.

With regard to policy implementation, implementers who understand the content of the policy and the policy environment are urgently needed, because in the action policy, the national insight of the implementer does not take action carelessly, because the issue of national insight is a sensitive issue among the public today. For this reason, collective action is needed from all interested parties.

\section{CONCLUSION}

Based on the results of the identification of research facts on the results of the analysis and discussion, there are several factors that hinder the implementation process of the National Insights Policy in Pandeglang Regency, including: The Capability of the National Insights Education Center Team is Not Appropriate, Community Participation is still low, Budget Limitations for the Implementation of National Insights Education. All of these factors illustrate the influence both from internal government and external from the government which hinders the process of implementing a collaborative national insight policy. 
The implementation of the National Insight Policy so that it can be carried out collaboratively, really needs to pay attention to actors or interested parties to be actively involved in the policy implementation process and also need to pay attention to some of the core policies of implementing policies to support the implementation of activities related to the actors involved.

The Policy Implementation Collaboration Model designed by the Researcher "Integrated Collaboration Process" has a philosophical meaning that describes a shield to become a protective policy implementation in collaboration which describes the relationship between actors consisting of: Citizen, Regulator, Academic, Media, and Implementers who carry out activities in support each actor is comprehensively interrelated by paying attention to three cores, namely: Content Policy, Environment Policy, Core of Conduct, Information Technology.

The importance of the quality and capability of each actor in implementing the national insight policy, not only contextually the value of the national insight, but more than that, capabilities are needed in practicing the values of the national insight as a role model for citizens as both the object and the subject of the national insight policy. Apart from that, it is necessary to have adequate budget support to support the implementation program of the national insight policy.

The implementation model of the national insight policy becomes the flow of the process of implementing the national insight policy which is carried out in collaboration with attention to key actors, by connecting activities related to each actor and requiring 3 aspects that support the implementation of the model.

\section{REFERENCES}

1. Ansell, C., \& Gash, A. (2008). Collaborative governance in theory and practice. Journal of Public Administration Research and Theory, 18(4), 543-571.

2. Anderson, B. (2004). Komunitas-komunitas Terbayang. Yogyakarta: Pustaka Pelajar.

3. Dunn, W. N. (2003). Pengantar Analisis Kebijakan Publik. Yogyakarta: Gajah Mada University Press.

4. Effendy, K. (2010). Memadukan Metode Kuantitaf dan Kualitatif. Bandung: Indra Prahasta.

5. Hadi, O. H. (2009). Nation and Character Building Melalui Pemahaman Wawasan Kebangsaan. Direktorat Politik, Komunikasi, dan Informasi Bappenas.

6. Hamdi, M. (2014). Kebijakan Publik: Proses, Analisis, dan Partisipasi. Jakarta: Ghalia Indonesia.

7. Jones, C. O. (1994). Pengantar Kebijakan Publik. Jakarta: RajaGrafindo Persada.

8. Knight, J., \& Jack, K. (1992). Institutions and Social Conflict. Cambridge University Press. 
9. Kodhi, S. A., \& Soejadi, R. (1989). Filsafat, Ideologi dan Wawasan Bangsa Indonesia. Yogyakarta: Universitas Atma Jaya.

10. Kohn, H. (1958). Nasionalisme, Arti dan Sedjarahnja. Jakarta: Pembangunan.

11. Lawang, R. M. (2015). Beberapa Hipotesis Tentang Eksklusi Sosial di Indonesia. Jurnal Ilmu Sosial Mamangan, 3(2), 1-6.

12. Lestari, G. (2016). Bhinnekha Tunggal Ika: Khasanah Multikultural Indonesia di Tengah Kehidupan SARA. Jurnal Pendidikan Pancasila dan Kewarganegaraan, 28(1).

13. Lon, Y. (2019). Membangun Manusia Seutuhnya: Perspektif Agama, Kebudayaan dan Pendidikan. Manggarai: Penerbit Unika Santu Paulus Ruteng.

14. Öberg, P., \& Uba, K. (2014). Civil society making political claims: outcries, interest advocacy, and deliberative claims. Public Administration Review, 74(3), 413-422.

15. Oberschall, A. (1973). Social Conflict and Social Movements. Englewood Cliffs, NJ: Prentice-Hall.

16. Robbins, S. P., \& Judge, T. A. (2008). Perilaku Organisasi. Jakarta: Salemba Empat.

17. Rubin, J. Z., Pruitt, D. G., \& Kim, S. H. (1994). Social Conflict: Escalation, Stalemate, and Settlement. Mcgraw-Hill Book Company.

18. Saebani, B. A. (2016). Perspektif Perubahan Sosial. Bandung: Pustaka Setia.

19. Sharma, G., Bao, X., \& Peng, L. (2014). Public Participation and Ethical Issues on E-Governance: A Study Perspective in Nepal. Electronic Journal of EGovernment, 12(1), 82.

20. Soekanto, S. (1983). Teori sosiologi tentang perubahan sosial. Ghalia Indonesia, Jakarta.

21. Soekarno. (1965). Di Bawah Bendera Revolusi. Jakarta: Gunung Agung.

22. Sugiyono, D. (2010). Metode penelitian kuantitatif dan RED. Bandung: Alfabeta.

23. Suharto, E. (2005). Analisis kebijakan publik: panduan praktis mengkaji masalah dan kebijakan sosial. Alfabeta.

24. Wasistiono, S. (2015). Perkembangan Konsep Negara Bangsa (Nation State) dalam Era Globalisasi (Tinjauan dari Sudut Pemerintahan). Kemenkopolhukkam Discussion Material on 7 October 2015. 